\section{Effect of Temperature on Demography and Predation Rate of Menochilus sexmaculatus (Coleoptera: Coccinellidae) Reared on Phenacoccus solenopsis (Hemiptera: Pseudococcidae)}

\author{
Ayesha Iftikhar ${ }^{1, *}$, Muhammad Asif Aziz ${ }^{1}$, Muhammad Naeem ${ }^{1}$, Munir Ahmad \\ and Tariq Mukhtar ${ }^{2}$ \\ ${ }^{1}$ Department of Entomology, Pir Mehr Ali Shah, Arid Agriculture University, \\ Rawalpindi \\ ${ }^{2}$ Department of Plant Pathology, Pir Mehr Ali Shah, Arid Agriculture University, \\ Rawalpindi
}

\begin{abstract}
A B S T R A C T
Zigzag beetle, Menochilus sexmaculatus Fabricius (Coleoptera: Coccinellidae) is an important predator of cotton mealy bug, Phenacoccus solenopsis Tinsley (Hemiptera: Pseudococcidae). Understanding the effect of temperature variations on its demography and predation rate is necessary to predict the population dynamics of this beetle against cotton mealy bug. Age-stage, two sex life tables of zigzag beetle were constructed at three different temperature regimes: $24 \pm 0.5{ }^{\circ} \mathrm{C}$ and $27 \pm 0.5{ }^{\circ} \mathrm{C}$ with $60-70 \%$ R.H. and ambient condition $\left(32 \pm 4{ }^{\circ} \mathrm{C} ; 16-50 \%\right.$ R.H.) with $14: 10 \mathrm{~h}$ (L:D) photoperiod using cotton mealy bug as a host. According to the results, the immature duration and adult longevity were comparatively longer at lower temperature $\left(24 \pm 0.5^{\circ} \mathrm{C}\right)$ and shorter at higher temperatures. Among population dynamic parameters, net reproductive rate $\left(R_{0}\right)$ was $216.52,105.99$ and 27.07 off-springs per individual, intrinsic rate of increase $(r)$ was $0.1543,0.1600$ and 0.1518 off-springs per female per day at $27 \pm 0.5,24 \pm 0.5$, and 32 $\pm 4.0^{\circ} \mathrm{C}$, respectively. Survival rate $\left(s_{x j}\right)$ and age-stage specific fecundity $\left(f_{x-7}\right)$ were greater at $24 \pm 0.5$ ${ }^{\circ} \mathrm{C}$. Among immature stages, $4^{\text {th }}$ instar was the most voracious with highest predation rate. Adult females consumed more cotton mealy bug nymphs at $24 \pm 0.5^{\circ} \mathrm{C}$. Net predation rate $\left(C_{0}\right)$ of the beetle was 5548 , 4463.2 and 2016.90 at $24 \pm 0.5^{\circ} \mathrm{C}, 27 \pm 0.5^{\circ} \mathrm{C}$ and $32 \pm 4^{\circ} \mathrm{C}$, respectively. The values of transformational rate $\left(Q_{p}\right)$ exhibited that $25.62,42.11$ and 74.50 nymphs of $P$. solenopsis were required per female beetle to lay one egg at $24 \pm 0.5^{\circ} \mathrm{C}, 27 \pm 0.5^{\circ} \mathrm{C}$ and $32 \pm 4^{\circ} \mathrm{C}$, respectively. Finite predation rate $(\omega)$ was more (7.64) at $24 \pm 0.5^{\circ} \mathrm{C}$ followed by $27 \pm 0.5^{\circ} \mathrm{C}(6.56)$ and the lowest at $32 \pm 4{ }^{\circ} \mathrm{C}(0.66)$. Adult beetles proved strong natural enemies of $P$. solenopsis. Our study provides detailed basic information for successful rearing of $M$. sexmaculatus in the laboratory and use as a bio-control agent against cotton mealy bug in the field at different temperature conditions.
\end{abstract}

\begin{tabular}{l} 
Article Information \\
Received 22 November 2016 \\
Revised 12 August 2017 \\
Accepted 19 February 2018 \\
Available online 16 August 2018 \\
Authors' Contribution \\
\hline AI and MAA conceived and \\
designed the study. AI conducted the \\
experiment and analyzed the data. \\
MA provided technical assistance in \\
writing results and discussion. MN \\
and TM guided in research work. \\
Key words \\
\hline Age-stage two sex, Life table, \\
Menochilus sexmaculatus, \\
Phenacocus solenopsis, Predation \\
rate.
\end{tabular}

Article Information

Revised 12 August 2017

Accepted 19 February 2018

August 2018

Authors' Contribution

designed the study. AI conducted the

experiment and analyzed the data.

MA provided technical assistance in

writing results and discussion. MN

Age-stage two sex, Life table,

Phenacoccus solenopsis, Predation

rate.

\section{INTRODUCTION}

$\mathrm{C}$ otton mealy bug, Phenacoccus solenopsis Tinsley (Hemiptera: Pseudococcidae) caused losses of 3.1 million cotton bales during 2006-07 in the Punjab, Pakistan (Mahmood et al., 2011). It is a polyphagous insect pest which infests almost 194 plant species identified as crops, fruits, vegetables and ornamental plants (Vennila et al., 2011; Hameed et al., 2012). Ladybird beetles are known to be effective bio-control agents against mealy bugs (Ali and Rizvi, 2009; Michaud, 2001). A large number of

\footnotetext{
* Corresponding author: aishaiftkhr@yahoo.com 0030-9923/2018/0005-1885 \$ 9.00/0

Copyright 2018 Zoological Society of Pakistan
}

predatory coccinellids have been identified as effective biocontrol agents of cotton mealy bug (Michaud, 2001; Rafi et al., 2005; Ali and Rizvi, 2009). Among these, zigzag beetle Menochilus sexmaculatus Fabricius (Coleoptera: Coccinellidae) has been suggested to be the promising biocontrol agent against cotton mealy bug (Arif et al., 2012), as well as other soft bodied insects including aphids, plant hoppers, thrips, jassids, scale insects and white flies (Rahman et al., 1993; Solangi et al., 2007). This beetle is widely distributed in South Western Asia, Indonesia, Philippines, South Africa, India and Pakistan.

Being poikilothermic organisms, the development, reproduction and predatory potential of insects is affected to a great extent by temperature variations in the environment. Insects perform best only at a certain 
temperature range (Roy et al., 2002; Rana, 2006; Pakyari and Enkegaard, 2012). Life table studies of a predator at varying temperatures can provide detailed information about survivorship, development, mortality and life expectancy (Ali and Rizvi, 2007, 2008). Most of the previous studies on $M$. sexmaculatus were focused on exploring its predatory potential against different aphid species (Mari et al., 2004; Ali and Rizvi, 2009; Saleem et al., 2014) and cotton mealy bug (Arif et al., 2011, 2012; Ali et al., 2013). An insect with better population growth rate in a particular condition does not necessarily mean an efficient predator (Yu et al., 2013).Therefore, predation rate must be considered along with population growth potential in life table under different temperature regimes to assess the efficacy of a particular predator (Chi et al., 2011).

The present study was designed to determine the effect of temperature on demographic parameters and predation rate of $M$. sexmaculatus against $P$. solenopsis. This study was based on the hypotheses that (a) temperature influences parameters of demography and predation rate of M. sexmaculatus (b) development and predation rates among individuals and between sexes determine the variations of predatory potential of $M$. sexmaculatus, and (c) finite predation rate of (both male and female adult) beetles also influence the predatory potential at a particular temperature.

\section{MATERIALS AND METHODS}

Demographic studies of zigzag beetle on cotton mealy bug were conducted at three sets of temperature; $24 \pm 0.5$ ${ }^{\circ} \mathrm{C}, 27 \pm 0.5^{\circ} \mathrm{C}$ and ambient temperature condition $(32 \pm 4$ ${ }^{\circ} \mathrm{C}$ ). In first two temperatures, R. H. was kept at $60-70 \%$ and for ambient laboratory condition, the temperature ranged from $28-36^{\circ} \mathrm{C}$ with $16-50 \%$ R. H. First two studies were conducted in growth chamber and the third was conducted in the laboratory at ambient conditions during the months of September and October, 2013. This is actually time of the year when cotton mealy bug population is at its peak in the cotton crop. The ambient temperature condition was used to compare development, reproduction and predation of beetle with those in controlled temperatures to get information for successful mass rearing of $M$. sexmaculatus.

\section{Field collection and rearing}

Cotton mealy bug was collected from Hibiscus rosachinensis Linnaeus (Malvales: Malvaceae) plants and reared on pumpkin Cucurbita pepo Linnaeus (Cucurbitales: Cucurbitaceae) fruits in enclosed containers to develop laboratory culture. Adult zigzag beetles were collected from Parthenium hysterophorus Linnaeus (Asterales:
Asteraceae) plants near University field area and were kept in petri dishes containing cotton mealy bugs and $10 \%$ honey solution as a food. Before using for life table studies, twenty pairs of $M$. sexmaculatus were reared on cotton mealy bugs at each set of temperature i.e., $24{ }^{\circ} \mathrm{C}, 27$ ${ }^{\circ} \mathrm{C}$ and ambient condition $\left(32 \pm 4^{\circ} \mathrm{C}\right)$ for two generations. To maintain genetic variability of predatory zigzag beetles, more number of adult beetles were collected from field and added in the stock culture.

\section{Life table study of Menochilus sexmaculatus}

One hundred eggs of M. sexmaculatus were shifted to 100 petri dishes each for the three temperature treatments. Moulting and survival of each larval stage from $1^{\text {st }}$ to $4^{\text {th }}$ instar were carefully recorded daily. The adults were paired on the basis of their body size (female larger than male) and transferred to petri-dishes in order to observe their mating behaviour (Mari et al., 2004). Survival, adult longevity and fecundity of each female beetle were recorded daily until their death.

We constructed age-stage, two sex life table to estimate life table parameters of the beetles and population dynamics parameters $(r$, the intrinsic rate of increase; $\lambda$ finite rate of increase; $R_{0}$ the net reproductive rate, $T$ mean generation time) using TWOSEX-MSChart (Chi, 1988, 2012a; Chi and Liu, 1985). Differences in the development time, longevity and reproduction among $M$. sexmaculatus at three different temperatures were analyzed using one way ANOVA followed by multiple comparison with Tukey-Kramer test $(\mathrm{P}<0.05)$ (Dunnett, 1980). We used Bootstrap technique to calculate the means and standard errors for population dynamics parameters instead of Jackknife technique to avoid discrepancy between the estimated means (Chi and Yang, 2003).

\section{Predation rate of Menochilus sexmaculatus}

Twenty freshly laid eggs were separated from paired culture of M. sexmaculatus and shifted to twenty plastic petri dishes individually. After hatching, initially each $1^{\text {st }}$ instar grub was provided with twenty nymphs $\left(1^{\text {st }}\right.$ instar) of cotton mealy bug nymphs as a food. Then, daily consumption of prey increased at different rates as the grubs moulted to next stages under different temperature conditions. Final densities of prey consumed by $4^{\text {th }}$ instars grubs were 280 at $24 \pm 0.5{ }^{\circ} \mathrm{C}, 240$ at $27 \pm 0.5{ }^{\circ} \mathrm{C}$ and 160 at $32 \pm 4^{\circ} \mathrm{C}$, per day. After emergence from pupae, male and female beetles were paired and provided with different densities (starting from twenty per day) of $P$. solenopsis nymphs, which reached up to 500 at $24 \pm 0.5$ ${ }^{\circ} \mathrm{C}, 440$ at $27 \pm 0.5{ }^{\circ} \mathrm{C}$ and 300 at ambient condition (32 $\pm 4{ }^{\circ} \mathrm{C}$ ). Fecundity, survival rate and predation rate of $M$. sexmaculatus were recorded daily till death of individuals. 
Table I.- Comparison of developmental duration, adult longevity and fecundity of $M$. sexmaculatus at three different temperature conditions.

\begin{tabular}{|c|c|c|c|c|c|c|}
\hline \multirow[t]{3}{*}{ Parameters } & \multicolumn{6}{|c|}{ Temperature } \\
\hline & \multicolumn{2}{|c|}{$24 \pm 0.5^{\circ} \mathrm{C}$} & \multicolumn{2}{|c|}{$27 \pm 0.5^{\circ} \mathrm{C}$} & \multicolumn{2}{|c|}{ Ambient condition $\left(32 \pm 4^{\circ} \mathrm{C}\right)$} \\
\hline & $\mathbf{n}$ & Mean \pm SE & $\mathbf{n}$ & Mean \pm SE & $\mathbf{n}$ & Mean \pm SE \\
\hline \multicolumn{7}{|l|}{ Developmental time (d) } \\
\hline Egg & 86 & $4.00 \pm 0.00 \mathrm{a}$ & 83 & $3.00 \pm 0.00 \mathrm{~b}$ & 71 & $2.00 \pm 0.00 \mathrm{c}$ \\
\hline Larva 1 & 76 & $4.27 \pm 0.08 \mathrm{a}$ & 67 & $2.87 \pm 0.11 \mathrm{~b}$ & 50 & $1.35 \pm 0.08 \mathrm{c}$ \\
\hline Larva 2 & 67 & $3.51 \pm 0.06 \mathrm{a}$ & 57 & $2.46 \pm 0.08 b$ & 39 & $1.82 \pm 0.08 \mathrm{c}$ \\
\hline Larva 3 & 60 & $3.13 \pm 0.04 \mathrm{a}$ & 51 & $3.33 \pm 0.06 b$ & 34 & $1.90 \pm 0.10 \mathrm{c}$ \\
\hline Larva 4 & 55 & $4.68 \pm 0.08 \mathrm{a}$ & 48 & $4.49 \pm 0.07 \mathrm{~b}$ & 33 & $2.59 \pm 0.15 \mathrm{c}$ \\
\hline Pupa & 53 & $4.64 \pm 0.07 \mathrm{a}$ & 45 & $4.40 \pm 0.08 \mathrm{~b}$ & 24 & $4.00 \pm 0.00 \mathrm{c}$ \\
\hline Pre-adult & 53 & $24.3 \pm 0.17 \mathrm{a}$ & 45 & $20.9 \pm 0.19 b$ & 24 & $14.2 \pm 0.36 \mathrm{c}$ \\
\hline \multicolumn{7}{|l|}{ Adult longevity (d) } \\
\hline Female & 38 & $26.79 \pm 0.23 \mathrm{a}$ & 31 & $20.52 \pm 0.27 b$ & 14 & $15.07 \pm 0.69 \mathrm{c}$ \\
\hline Male & 15 & $17.20 \pm 0.26 \mathrm{a}$ & 14 & $14.00 \pm 0.36 \mathrm{~b}$ & 10 & $12.80 \pm 0.33 \mathrm{c}$ \\
\hline Fecundity (egg/female) & 38 & $570.0 \pm 8.99 \mathrm{a}$ & & $342.0 \pm 7.31 \mathrm{~b}$ & & $1936 \pm 22.8 \mathrm{c}$ \\
\hline Daily maximum & & 120 & & 175 & & 92 \\
\hline Lifelong maximum & & 674 & & 401 & & 315 \\
\hline
\end{tabular}

Temperatures sharing similar letters have no significant difference based on Tukey-Kramer procedure at $5 \%$ level of significance.

Data of predation rate of $M$. sexmaculatus individuals at each temperature were analyzed by CONSUMEMSChart (Chi, 2012b). Age-specific predation rate, $k_{x}$ (mean number of predator beetle to consume prey at age $x$ ), age specific net predation rate, $q_{x}$ (a relationship of age-specific survival rate $\left(l_{x}\right)$ to age-specific predation rate $\left(k_{x}\right)$ which indicates the weighted number of $1^{\text {st }}$ nymphal instar of $P$. solenopsis fed by $M$. sexmaculatus at age $x$ ), net predation rate, $C_{0}$ (mean number of $1^{\text {st }}$ nymphal instar of $P$. solenopsis consumed by predator beetle during entire life, which is the summation of $q_{x}$ at all age group of population), transformation rate, $Q_{p}$ (the ratio of net reproductive rate $R_{0}$ over net predation rate $C_{0}$ which gives information about the number of $P$. solenopsis consumed by predator beetle for production of eggs), stable predation rate $(\Psi)$ and finite predation rate $(\omega)$, were also calculated (Chi et al., 2011).

\section{RESULTS AND DISCUSSION}

Age-stage two sex, life table of Menochilus sexmaculatus

There was a considerable variation in number of eggs hatching from three cohorts (100 eggs) of M. sexmaculatus; 86,83 and 71 at $24 \pm 0.5,27 \pm 0.5$ and $32 \pm 4{ }^{\circ} \mathrm{C}$, respectively (Table I). Decrease in hatching period with increasing temperature has also been reported by Ali et al. (2012) and Veeravel and Baskaran (1996) while studying the predatory potential of $M$. sexmaculatus on aphids. There was a significant decrease in the development periods of larval and pupal stages with increasing temperature. Pre- adult duration was completed in 24.3 days at $24 \pm 0.5^{\circ} \mathrm{C}$ and in 14.2 days at ambient condition $\left(32 \pm 4^{\circ} \mathrm{C}\right)$. Same trend was observed in case of adult males and females. Adult female longevity was 26.79 days at $24 \pm 0.5{ }^{\circ} \mathrm{C}$ and 15.07 days at $32 \pm 4{ }^{\circ} \mathrm{C}$, while adult male longevity was recorded 17.20 days at $24 \pm 0.5^{\circ} \mathrm{C}$ and 12.80 days at 32 $\pm 4{ }^{\circ} \mathrm{C}$, respectively. Females had longer adult duration as compared to males. Maximal daily fecundity increased from $24 \pm 0.5^{\circ} \mathrm{C}$ to $27 \pm 0.5^{\circ} \mathrm{C}$ and decreased at ambient condition. Maximum life time fecundity was the highest (674) at $24 \pm 0.5^{\circ} \mathrm{C}$ followed by that (401) at $27 \pm 0.5^{\circ} \mathrm{C}$ and the lowest (315) at ambient condition. Our studies are in agreement with the findings of Mari et al. 2004) who reported shorter life span of $M$. sexmaculatus males than females, on alfalfa aphids (Therioaphis trifolii Monell). The survival rate and total fecundity of $M$. sexmaculatus was better at $24 \pm 0.5^{\circ} \mathrm{C}$ and $27 \pm 0.5^{\circ} \mathrm{C}$ as compared to ambient condition $\left(32 \pm 4{ }^{\circ} \mathrm{C}\right)$, which reflected negative effect of high $\left(>28^{\circ} \mathrm{C}\right)$ temperature on the performance of M. sexmaculatus.

Age-stage specific survival rate $\left(s_{x j}\right)$ of $M$. sexmaculatus (the probability that freshly laid eggs will survive to age $x$ and develop to the stage $j$ ) was plotted in Figure 1, which showed overlapping curves, illustrating differences in developmental rates in both immature and mature stages. The first adults emerged at the age of 22 , 16 and 12 days and the survival rates were 29.08, 50.02 and 17.64 at $24 \pm 0.5{ }^{\circ} \mathrm{C}, 27 \pm 0.5{ }^{\circ} \mathrm{C}$ and $32 \pm 4^{\circ} \mathrm{C}$, respectively (Fig. 1).

The age-specific survival rate $\left(l_{x}\right)$ is the probability 
of newly hatched egg to survive at age $x$. It ignores the individual developmental rate and stage discrepancy. Agestage specific fecundity $\left(f_{x j}\right)$ explains mean number of eggs laid per adult female at age $x$ and stage $j$ per day (adult female of $M$. sexmaculatus was at $7^{\text {th }}$ life stage) and only counts female individuals which were able to produce eggs. Age-specific fecundity $\left(m_{x}\right)$ describes the fecundity of emerged larvae to adult age $x$; this is why age-stage specific fecundity $\left(f_{x 7}\right)$ curves showed higher peaks than the age-specific fecundity $\left(m_{x}\right)$ curves (Fig. 2). First egg laying occurred on $26^{\text {th }}, 20^{\text {th }}$ and $15^{\text {th }}$ day with $\left(f_{x 7}\right)$ value of $0.1944,1.556$ and 1.000 eggs per female per day at 24 $\pm 0.5{ }^{\circ} \mathrm{C}, 27 \pm 0.5{ }^{\circ} \mathrm{C}$ and $32 \pm 4^{\circ} \mathrm{C}$, respectively. Agespecific fecundity $\left(m_{x}\right)$ was $0.132,0.304$ and 0.333 females per female per day at age of $26^{\text {th }}$ day, $20^{\text {th }}$ day and $15^{\text {th }}$ day with age specific survival $\left(l_{x}\right)$ was $0.53,0.46$ and 0.24 days at $24 \pm 0.5{ }^{\circ} \mathrm{C}, 27 \pm 0.5{ }^{\circ} \mathrm{C}$ and $32 \pm 4{ }^{\circ} \mathrm{C}$, respectively. The peak of age-stage specific fecundity $\left(f_{x 7}\right)$ was 71.52 , 69.58 and 38.84 eggs per female per day at the age of $33^{\text {rd }}, 29^{\text {th }}$ and $20^{\text {th }}$ days, at $24 \pm 0.5^{\circ} \mathrm{C}, 27 \pm 0.5^{\circ} \mathrm{C}$ and $32 \pm 4^{\circ} \mathrm{C}$, respectively. Higher peaks of $m_{x}, l_{x} m_{x}$ and $f_{x 7}$ were observed at $24 \pm 0.5^{\circ} \mathrm{C}$ and the lowest at $32 \pm 4{ }^{\circ} \mathrm{C}$.

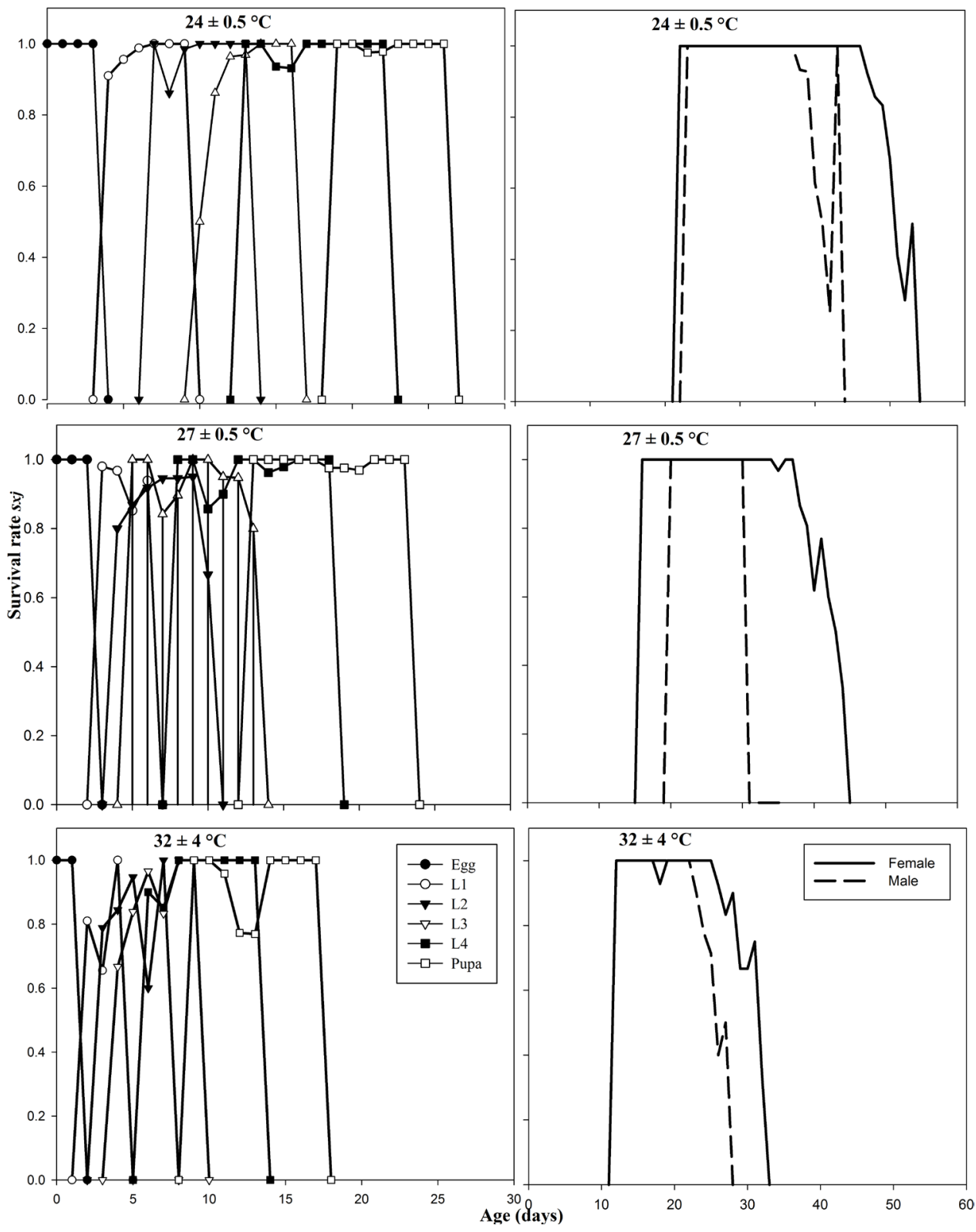

Fig. 1. Age-stage specific survival rate (Sx, i) of M. sexmaculatus reared on P. solenopsis at different temperatures. 


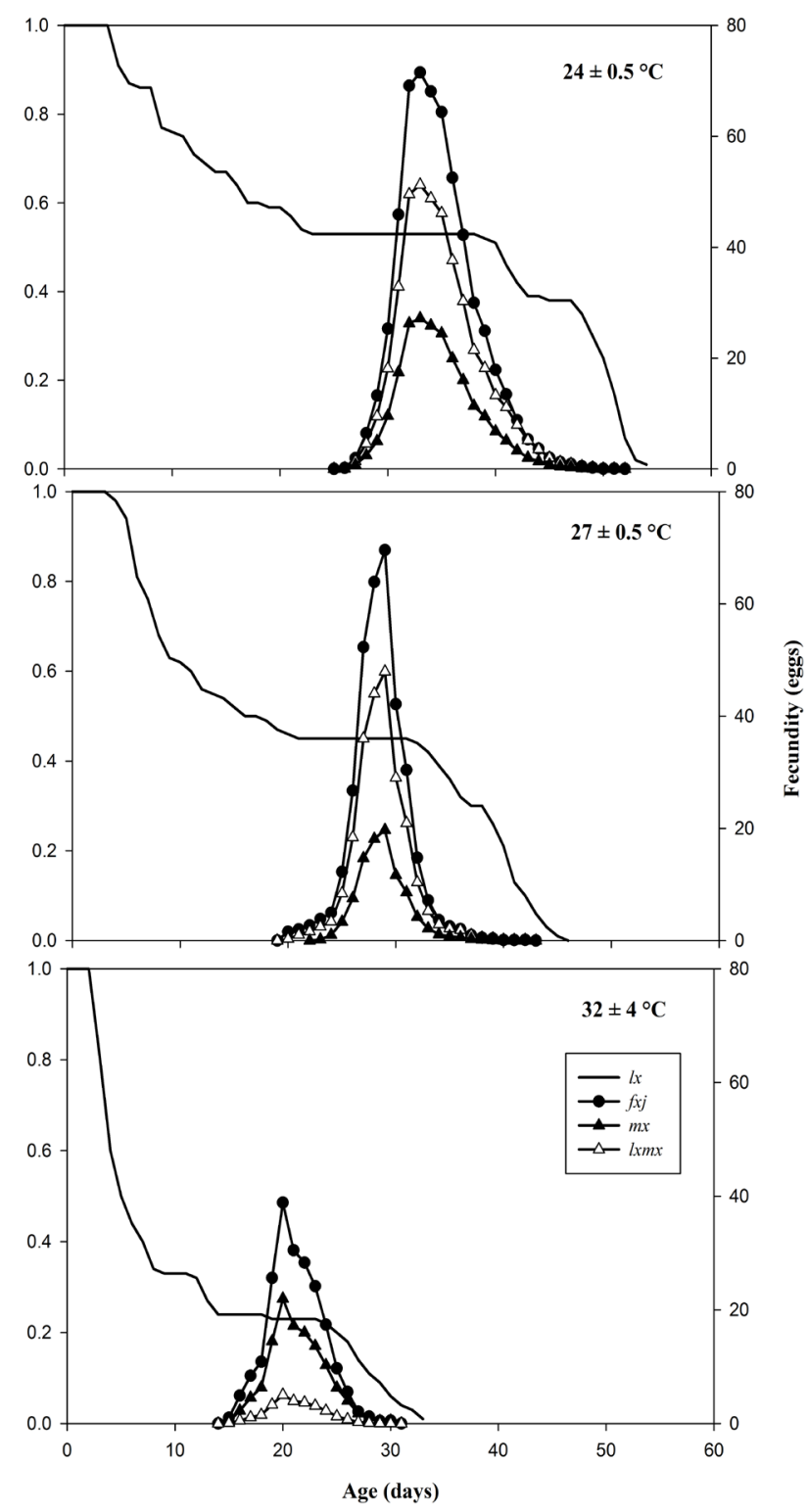

Fig. 2. Age specific survival rates $\left(l_{x}\right)$, fecundities $\left(m_{x}\right)$, maternities $\left(l_{x} m_{x}\right)$ and age-stage specific fecundities $\left(f_{x 7}\right)$ of $M$. sexmaculatus reared on $P$. solenopsis at different temperatures.

Traditional female age-specific life tables (Birch, 1948) do not provide information regarding stage differentiation, role of male individuals in the population, variable survival rate of different stages and their overlaps in the life history of insects (Chi ,1988; Yu et al., 2005; Chi and Su, 2006; Huang and Chi, 2012). We used age-stage, two sex life tables because it accounts variable developmental rate among individuals and stage differentiation of both sexes while calculating population parameters.

\section{Population dynamics parameters}

Population dynamic parameters, estimated by using Bootstrap method, reflected strong effect of temperature (Table II) (Efron and Tibshiramin, 1993). Intrinsic rate of increase $(r)$ increased with increasing temperature; from $0.1543,0.1600$ and 0.1518 females per female per day at 24 $\pm 0.5^{\circ} \mathrm{C}, 27 \pm 0.5^{\circ} \mathrm{C}$ but declined at $32 \pm 4^{\circ} \mathrm{C}$. Due to faster development, higher daily production of eggs and earlier peaks, reproduction was higher at $27 \pm 0.5^{\circ} \mathrm{C}$ than at $24 \pm$ $0.5^{\circ} \mathrm{C}$. Finite rate of increase $(\lambda)$ followed the same trend as exhibited by intrinsic rate of increase $(r)$. The highest net reproductive rate $\left(R_{0}\right)$ of 216 offspring per individual was noted at $24 \pm 0.5^{\circ} \mathrm{C}$ and the lowest (27.07 offspring per individual) at $32 \pm 4{ }^{\circ} \mathrm{C}$. Mean generation time $(T)$ was the longest ( 34.86 days) at $24 \pm 0.5^{\circ} \mathrm{C}$ and the shortest (21.73 days) at $32 \pm 4^{\circ} \mathrm{C}$. Life table studies of Harmonia dimidiata on Aphis gossypii also showed decrease in mean generation time $(T)$ and net reproductive rate $\left(R_{0}\right)$ with increasing temperature Yu et al (2013). Insects can tolerate temperature changes only up to certain limits and beyond those limits their life activities are negatively affected (Hameed et al., 2012). Same phenomena were observed in the current studies; faster rate of development, higher daily egg production and earlier peaks in reproduction at $27 \pm 0.5^{\circ} \mathrm{C}$ than at $24 \pm 0.5^{\circ} \mathrm{C}$. However, variability in temperature as for ambient condition showed faster development but decreased survival rate and fecundity.

\section{Predation rate of Menochilus sexmaculatus}

Predation rate of $M$. sexmaculatus larvae increased rapidly from $1^{\text {st }}$ to $4^{\text {th }}$ instars. Predation increased with the progress of the larval instar (Unal et al., 2017) Total number of mealy bugs fed during immature stages was $1730,1430.61$ and 614 per larva at $24 \pm 0.5^{\circ} \mathrm{C}, 27 \pm 0.5$ ${ }^{\circ} \mathrm{C}$ and $32 \pm 4{ }^{\circ} \mathrm{C}$, respectively (Table III). Predation rate of both female and male adults was higher as compared to different larval instars. During whole life span, female consumed significantly more mealy bugs than those of males at all temperature regimes. M. sexmaculatus adult females consumed maximum cotton mealy bugs (5199) at $24 \pm 0.5^{\circ} \mathrm{C},(3889.7)$ at $27 \pm 0.5^{\circ} \mathrm{C}$ and minimum (1905.83) at $32 \pm 04{ }^{\circ} \mathrm{C}$. Predation rate of $M$. sexmaculatus increased with age; the fourth instar to be the most voracious among all larval instars. Similar findings were reported by Saleem et al. (2014) while studying the predation efficacy of M. sexmaculatus against Macrosiphum rosae under laboratory conditions. They found $4^{\text {th }}$ instar consuming more preys/day of Rhopalosiphum maidis, Aphis gossypii and Therioaphis trifolii than their earlier instars. Female $M$. sexmaculatus with long life period showed more predatory potential than males against $R$. padi at varying temperature conditions Ali et al. (2012). In our study, females almost consumed more than twice the number of preys than by 
Table II.- Population dynamic parameters of $M$. sexmaculatus reared on $P$. solenopsis at three different temperatures estimated by all individuals and Bootstrap technique.

\begin{tabular}{|c|c|c|c|c|}
\hline \multicolumn{2}{|c|}{ Parameters } & \multirow{2}{*}{$\begin{array}{c}\mathbf{2 4} \pm \mathbf{0 . 5}{ }^{\circ} \mathrm{C} \\
0.1543\end{array}$} & \multirow{2}{*}{$\begin{array}{c}\mathbf{2 7} \pm \mathbf{0 . 5}{ }^{\circ} \mathrm{C} \\
0.1600\end{array}$} & \multirow{2}{*}{$\begin{array}{c}\begin{array}{c}\text { Ambient condition }(\mathbf{3 2} \pm \mathbf{4} \\
\left.{ }^{\circ} \mathbf{C}\right)\end{array} \\
0.1518\end{array}$} \\
\hline$r_{m}$ & All individuals & & & \\
\hline & Bootstrap technique & $0.1540 \pm 0.0040 \mathrm{~b}$ & $0.1596 \pm 0.0057 \mathrm{a}$ & $0.1497 \pm 0.0139 c$ \\
\hline \multirow[t]{2}{*}{$\lambda$} & All individuals & 1.1668 & 1.1735 & 1.1639 \\
\hline & Bootstrap technique & $1.1665 \pm 0.0046 \mathrm{~b}$ & $1.1731 \pm 0.0066 \mathrm{a}$ & $1.1616 \pm 0.0161 \mathrm{c}$ \\
\hline \multirow[t]{2}{*}{$R_{o}$} & All individuals & 216.52 & 105.99 & 27.07 \\
\hline & Bootstrap technique & $216.42 \pm 27.93 \mathrm{a}$ & $105.89 \pm 15.81 b$ & $26.99 \pm 7.36 \mathrm{c}$ \\
\hline \multirow[t]{2}{*}{$T$} & All individuals & 34.86 & 29.14 & 21.73 \\
\hline & Bootstrap technique & $34.87 \pm 0.21 \mathrm{a}$ & $29.15 \pm 0.35 b$ & $21.76 \pm 0.49 \mathrm{c}$ \\
\hline
\end{tabular}

$R_{o}$, net reproductive rate; $r_{m}$, intrinsic rate of natural increase; $T$, mean generation time; $\lambda$, finite rate of increase. Temperatures sharing similar letters have no significant difference based on Tukey-Kramer procedure at $5 \%$ level of significance.

Table III.- Comparison of predation rate of $M$. sexmaculatus on first nymphal instar of $P$. solenopsis at three different temperatures.

\begin{tabular}{|c|c|c|c|c|}
\hline \multicolumn{2}{|l|}{ Life stages } & \multirow{2}{*}{$\begin{array}{c}\mathbf{2 4} \pm \mathbf{0 . 5}{ }^{\circ} \mathbf{C} \\
98.50 \pm 0.95 a\end{array}$} & \multirow{2}{*}{$\begin{array}{c}\mathbf{2 7} \pm \mathbf{0 . 5}{ }^{\circ} \mathbf{C} \\
51.700 \pm 1.140 b\end{array}$} & \multirow{2}{*}{$\begin{array}{c}\text { Ambient condition }\left(\mathbf{3 2} \pm \mathbf{4}^{\circ} \mathbf{C}\right) \\
14.60 \pm 0.82 \mathrm{c}\end{array}$} \\
\hline Larval stage & L1 & & & \\
\hline & $\mathrm{L} 2$ & $204.0 \pm 6.56 \mathrm{a}$ & $135.45 \pm 5.960 \mathrm{~b}$ & $79.60 \pm 0.83 \mathrm{c}$ \\
\hline & L3 & $426.0 \pm 10.3 \mathrm{a}$ & $336.90 \pm 13.03 b$ & $150.9 \pm 1.70 \mathrm{c}$ \\
\hline & L4 & $996.0 \pm 9.28 \mathrm{a}$ & $899.00 \pm 11.16 b$ & $371.8 \pm 1.98 \mathrm{c}$ \\
\hline Total pre-adult & $1^{\text {st }}$ to $4^{\text {th }}$ Instar & $1730 \pm 10.50 \mathrm{a}$ & $1430.61 \pm 5.55 b$ & $614.0 \pm 4.39 \mathrm{c}$ \\
\hline \multirow[t]{2}{*}{ Adult stage } & Female & $5199.0 \pm 191 \mathrm{a}$ & $3889.7 \pm 106.1 \mathrm{~b}$ & $1905.83 \pm 46.03 \mathrm{c}$ \\
\hline & Male & $2349.0 \pm 121 \mathrm{a}$ & $1586.5 \pm 93.24 b$ & $1282.50 \pm 2.020 \mathrm{c}$ \\
\hline \multirow[t]{2}{*}{ Total life span } & Female & $6947.0 \pm 190 \mathrm{a}$ & $5322.5 \pm 110.1 \mathrm{~b}$ & $2521.67 \pm 48.43 \mathrm{c}$ \\
\hline & Male & $4043.0 \pm 138 \mathrm{a}$ & $3009.50 \pm 84.0 \mathrm{~b}$ & $1891.00 \pm 1.730 \mathrm{c}$ \\
\hline \multicolumn{2}{|c|}{ Net Predation rate $(\mathrm{Co})$} & $5548.00 \pm 436$ & $4463.2 \pm 329.34$ & $2016.90 \pm 171.25$ \\
\hline \multicolumn{2}{|c|}{ Transformation rate $(Q p)$} & 25.62 & 42.11 & 74.500 \\
\hline \multicolumn{2}{|c|}{ Stable Predation rate $(\Psi)$} & 6.550 & 6.447 & 0.5632 \\
\hline \multicolumn{2}{|c|}{ Finite Predation rate $(\omega)$} & 7.640 & 6.5631 & 0.6559 \\
\hline
\end{tabular}

Temperatures sharing similar letters have no significant difference based on Tukey-Kramer procedure at 5\% level of significance.

those by males. This voracity of female may be due to their larger body size and longevity than males, which also require more energy to meet reproduction needs (Farhadi et al., 2011). At ambient conditions, the overall period of all stages was shorter but survival rate and fecundity were lower as compared to those in controlled conditions.

Age-specific net predation, $\left(q_{x}\right)$ is the mean number of cotton mealy bugs consumed by an average individual of M. sexmaculatus during its entire life span (Chi and Yang, 2003). Both age-specific predation rate $\left(k_{x}\right)$ and agespecific net predation rate $\left(q_{x}\right)$ showed two obvious curves at egg and pupal stage because at egg and pupal stages do not consume any prey (Fig. 3). These non-predatory phases could not be reflected with traditional life table. This is crucial to decide release intervals of natural enemies for effective biological control program (Yu et al., 2013). Net predation rate $\left(C_{0}\right)$ calculated by taking survival rates, predation rates and longevities of the zigzag beetle into consideration was the highest (5548 cotton mealy bugs) at $24 \pm 0.5{ }^{\circ} \mathrm{C}$ followed by that (4463.2 cotton mealy bugs) at $27 \pm 0.5{ }^{\circ} \mathrm{C}$. Transformation rate $\left(Q_{p}\right)$ provides a demographic estimation of the relationship between the reproductive rate and predation rate of the predator (Chi an Yang, 2003). $Q_{p}$ reflected that $M$. sexmaculatus required $25.62,42.11$ and 74.50 cotton mealy bugs $\left(1^{\text {st }}\right.$ instar) for the production of one egg at $24 \pm 0.5^{\circ} \mathrm{C}, 27 \pm$ $0.5^{\circ} \mathrm{C}$ and $32 \pm 4{ }^{\circ} \mathrm{C}$, respectively. More preys would be required for the beetle at $24 \pm 0.5^{\circ} \mathrm{C}$ than at $27 \pm 0.5^{\circ} \mathrm{C}$. Contribution of males towards predation of cotton mealy bug was different as compared to females (Table III) and stage differentiation of the beetle showed clear overlaps (Fig. 1). In contrast, traditional life tables theory do not 
consider sex variation and stage differentiation resulting in overestimation of results regarding predation capacity (Farhadi et al., 2011). In the current studies, we calculated both population dynamics parameters and predation rate of M. sexmaculatus against cotton mealy bug to avoid such over-estimation.
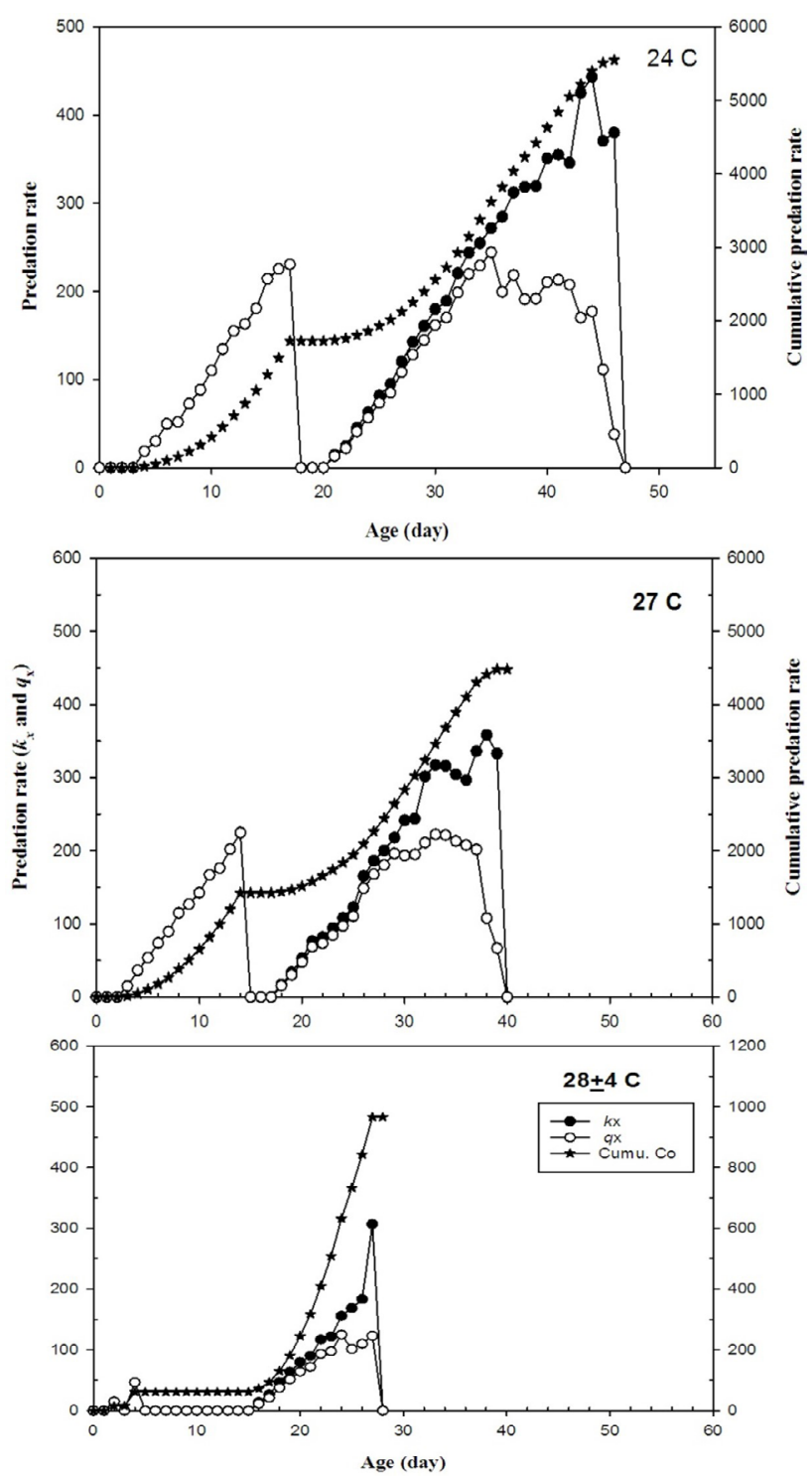

Fig. 3. Age-specific predation rates $(k x)$, age-specific net predation rates $(q x)$ of $M$. sexmaculatus reared on $P$. solenopsis at different temperatures.

Application of studies in laboratory rearing and biocontrol program

Growth potential and efficacy of the rearing program like development rate of larval stage, mortality rate, weight of fresh adults and abundance in the field and life table parameters have been assessed previously (Kalushkov, 1998; Atlehan and Kaydan, 2002; Soroushmehr et al., 2008). However, the efficacy of a predator cannot be determined precisely without considering its predation rate along with population growth rate. Although intrinsic rate of increase $(r)$ and finite rate of increase $(\lambda)$ of the beetle were higher at $27 \pm 0.5^{\circ} \mathrm{C}$, the net predation rate was high at $24 \pm 0.5^{\circ} \mathrm{C}$. But higher intrinsic rate of increase $(r)$ and finite rate of increase $(\lambda)$ do not indicate higher predatory potential of the predator. Therefore, finite predation rate $(\omega)$ was calculated keeping into consideration both population growth rate and predation rate to compare the predatory potential of the beetle (Chi et al., 2011). Because faster finite predation rate $(\omega)$ was observed at $24 \pm 0.5^{\circ} \mathrm{C}$ than $27 \pm 0.5{ }^{\circ} \mathrm{C}$, we can consider $M$. sexmaculatus as the more efficient predator of cotton mealy bug at $24 \pm 0.5^{\circ} \mathrm{C}$ than higher temperature regimes.

\section{CONCLUSION}

Stage-specific predation rate and life table parameters were used to assess the predator-prey relationship of $M$. sexmaculatus with $P$. solenopsis. We have demonstrated that, predation rate must be considered with reproductive rate of the beetle during life table studies to explore accurate predation capacity. At $24 \pm 0.5^{\circ} \mathrm{C}, M$. sexmaculatus is an efficient predator as compared to other temperature regimes. In order to get the next generation earlier, the rearing at $24 \pm 0.5{ }^{\circ} \mathrm{C}$ will save the labour expenses and consume less prey as a food.

Statement of conflict of interest

Authors have declared no conflict of interest.

\section{REFERENCES}

Agarwala, B.K. and Bardhanroy, P., 1999. Numerical response of lady bird beetles (Coleoptera: Coccinellidae) to aphid prey (Homoptera: Aphididae) in a field bean in North East India. $J$. appl. Ent., 123: 401-405.

Ali, A. and Rizvi, P.Q., 2007. Age specific survival and fecundity table of Coccinella septempunctata L. (Coleoptera: Coccinellidae) on different aphid species. Annls. Pl. Prot. Sci., 15: 329-334.

Ali, A. and Rizvi, P.Q., 2008. Effect of varying temperature on the survival and fecundity of Coccinella septempunctata L. (Coleoptera: Coccinellidae) fed on (Lipaphis erysimi). J. Ent., 5: 133-137. https://doi.org/10.3923/je.2008.133.137

Ali, A. and Rizvi, P.Q., 2009. Life table studies of 
Menochilus sexmaculatus Fabr. (Coleoptera: Coccinellidae) at varying temperature on (Lipaphis erysimi Kalt). J. World appl. Sci., 7: 897-901.

Ali, A., Haq, E., Khan, J., Gillani, W.A, Mahmood, T. and Javed, H.I., 2013. Effect of three constant temperatures on the biology and predatory potential of Menochilus sexmaculatus Fab. (Coleoptera: Coccinellidae) feeding on Schizaphis graminum aphid (Hemiptera: Aphididae). Pak. J. Ent., 35: 9598.

Ali, A., Haq, E., Rehman, A., Khan, J., Gillani, W.A. and Rauf, M., 2012. Biological parameters and predatory potential of Menochilus sexmaculatus Fab. (Coleoptera: Coccinellidae) at varying temperature on Rhopalosiphum padi L. Pak. J. agric. Res., 25: 318-322.

Ali, M., Perveen, R., Yousuf, M.J., Khawaja, S. and Amin, M., 2014. Predatory potential of five coccinellid predators against cotton mealy bug (Phenacoccus solenopsis Tinsley.) in laboratory and field conditions from Sindh, Pakistan. Pak. J. Ent., 36: 7-12.

Arif, M.J., Rafiq, M., Wazir, S., Mehmood, N. and Ghaffar, A., 2012. Studies on cotton mealy bug, Phenacoccus solenopsis (Pseudococcidae: Homoptera), and its natural enemies in Punjab, Pakistan. Int. J. agric. Biol., 14: 557-562.

Arif, M.J., Gogi, M.D., Abid, A.M., Imran, M., Shahid, M.R., Hussain, S. and Arshad, M., 2011. Pretadory potential of some native coccinellid predators against Phenacoccus solenopsis, Tinsely (Pseudococcidae: Hemiptera). Pak. Entomol., 33: 97-103.

Atlihan, R. and Kaydan, M.B., 2002. Development, survival and reproduction of three coccinellids feeding on Hyalopterus pruni (Geoffer) (Homoptera: Aphididae). Turk. J. Agric. For., 26: 119-124

Birch, L.C., 1948. The intrinsic rate of natural increase of an insect population. J. Anim. Ecol., 17: 15-26. https://doi.org/10.2307/1605

Chi, H. and H. Liu., 1985. Two new methods for the study of insect population ecology. Bull. Inst. Zool. Acad. Sin., 24: 225-240

Chi, H., 1988. Life-table analysis incorporating both sexes and variable development rates among individuals. J. environ. Ent., 17: 26-34. https://doi. org/10.1093/ee/17.1.26

Chi, H. and Yang, T.C., 2003. Two-sex life table and predation rate of Propylaea japonica Thunberg (Coleoptera: Coccinellidae) fed on Myzus persicae
(Sulzer) (Homoptera: Aphididae). J. environ. Ent., 32: 327-333. https://doi.org/10.1603/0046225X-32.2.327

Chi, H. and Su, H.Y., 2006. Age-stage two sex life table of Aphidius gifuensis (Ashmead) (Hymenoptera: Braconidae) and its host Myzus persicae (Sulzer) (Homoptera: Aphididae) with mathematical proof of the relationship between female fecundity and the net reproductive rate. J. environ. Ent., 35: 1021.

Chi, H., Mou, D.F., Allahyari, H., Yu, J.Z., Huang, Y.B., Yang, T.C., Farhadi, R. and Gholizadeh, M., 2011. Finite predation rate: A novel parameter for the quantitative measurement of predation potential of predator at population level. Available at: http:// hdl.handle.net/10101/npre.2011.6651.1.

Chi, H., 2012a. TWOSEX-MSChart: Computer program for age stage, two-sex life table analysis. Available at: http://140.120.197.173/ecology/.

Chi, H., 2012b. CONSUME-MSChart: Computer program for consumption rate analysis based on the age stage, two-sex life table. Available at: http://140.120.197.173/ecology/.

Dunnett, C.W., 1980. Pair wise multiple comparisons in the homogeneous variance, unequal sample size case. J. Am. Stat. Assoc., 75: 789-795. https://doi.or g/10.1080/01621459.1980.10477551

Efron, B. and Tibshirani, R.J., 1993. An introduction to the bootstrap. Chapman and Hall, New York. https://doi.org/10.1007/978-1-4899-4541-9

Farhadi, R., Allahyari, H. and Chi, H., 2011. Life table and predation capacity of Hippodamia variegata (Coleoptera: Coccinellidae) feeding on Aphis fabae (Hemiptera: Aphididae). J. biol. Contr., 59: 83-89. https://doi.org/10.1016/j.biocontrol.2011.07.013

Hameed, A., Aziz, M.A. and Aheer, G.M., 2012. Impact of ecological conditions on biology of cotton mealy bug, Phenacoccus solenopsis (Hemiptera: Pseudococcidae) in laboratory. Pakistan J. Zool., 44: 685-690.

Huang, Y.B. and Chi, H., 2012. Assessing the application of the jackknife and bootstrap techniques to the estimation of the variability of the net reproductive rate and gross reproductive rate: a case study in Bactrocera cucurbitae (Coquillett) (Diptera: Tephritidae). J. Agric. For., 61: 37-44.

Kalushkov, P., 1998. Ten aphid species (Sternorrhyncha: Aphididae) as prey for Adilia bipunctata (Coleoptera: Coccinellidae). Eur. J. Ent., 95: 343349.

Mahmood, R., Asalm, M.N., Solangi, G.S. and Samad, 
A., 2011. Historical perspective and achievements in biological management of cotton mealybug (Phenacoccus solenopsis) Tinsley in Pakistan. In: Proceedings of $5^{\text {th }}$ Meeting of ICAC's Asian Cotton Research and Development Network, 23-25 Feb, 2011 held at Lahore, Pakistan.

Mari, J.M., Nizamani, S.M., Lohar, M.K. and Khuhro, R.D., 2004. Biology of (Menochilus sexmaculatus Fab.) and Coccinella undecimpunctata L. (Coccinellidae: Coleoptera) on Alfalfa Aphid Therioaphis trifolii Monell. J. Asia-Pacific Ent., 7: 297-301. https://doi.org/10.1016/S12268615(08)60230-7

Michaud, S.P., 2001. Population dynamics of bean aphid (Aphis craccivora Koch) and its predatory coccinellid complex in relation to crop type (Lantil, Lathyrus and Faba bean) and weather conditions. $J$. entomol. Res., 18: 25-36.

Pakyari, H. and Enkegaard, A., 2012. Effect of different temperatures on consumption of two spotted mite, Tetranychus urticae, eggs by the predatory thrips, Scolothrips longicornis. J. Insect Sci., 12: 98. https://doi.org/10.1673/031.012.9801

Rafi, M.A., Irshad, M. and Inayatullah, M., 2005. Predatory ladybird beetles of Pakistan. PARC/ NWFP Agric Univ Roohani Art Press, Islamabad, Pakistan, pp. 105.

Rahman, M.H., Sardar, M.A., Miah, M.R.U. and Kamal, N.Q., 1993. Consumption rate of (Aphis medicaginis) by the grubs of (Menochilus sexmaculatus Fab.) Bangladesh J. Zool., 21: 185 187.

Rana, J.S., 2006. Response of Coccinella septempunctata and Menochilus sexmaculatus (Coleoptera: Coccinellidae) to their aphid prey, Lipaphis erysimi (Hemiptera: Aphididae) in rapeseed mustard. Eur. J. Ent., 103: 81-84. https://doi.org/10.14411/ eje. 2006.013

Roy, M., Brodeur, J., Cloutier, C., 2002. Relationship between temperature and development rate of Stethorus punctillum (Coleoptera: Coccinellidae) and its prey Tetranichus mcdanieli (Acari: Tetranychidae). J. environ. Ent., 31: 177-187. https://doi.org/10.1603/0046-225X-31.1.177

Saleem, M., Hussain, D., Anwar, H., Saleem, M., Ghous, G. and Abbas, M., 2014. Predation Efficacy of Menochilus sexmaculatus Fabricus (Coleoptera: Coccinellidae) against Macrosiphum rosae under laboratory conditions. J. Ent. Zool. Stud., 2: 160163.

Solangi, B.K., Hullio, M.H. and Baloch, N., 2007. Biological parameters and prey consumption by zigzag beetle, Menochilus sexmaculatus Fab. Rhopalosiphum maidis Fitch, Aphis gossypii Glover and Therioaphis trifolii (Monell). Sarhad J. Agric., 23: 1097-1101.

Soroushmehr, Z., Sahragard, A. and Salehi, L., 2008. Comparative life table statistics for the ladybeetle Scymnus syriacus reared on the green citrus aphid, Aphis spiraecola, fed on two host plants. J. entomol. Sci., 11: 281-288. https://doi.org/10.1111/j.14798298.2008.00275.x

Unal, S., Er,A., Akkuzu, E. and Salek, L., 2017. Predation efficacy of the predator Coccinella septempunctata L. on the aphid species Macrosiphum rosae (L.) in Kastamonu province, Turkey. Pakistan J. Zool., 49: 345-349.

Veeravel, R. and Baskaran, P., 1996. Temperaturedependent development, adult longevity, fecundity and feeding potential of two coccinellid predators under laboratory conditions. J. Ent., 21: 13-18.

Vennila, S., Prasad, Y.G., Prabhakar, M., Kumar, R., Nagrare, V., Amutha, M., Dharajyothi, Agarwal, M., Sreedevi, G., Venkateswarlu, B., Kranthi, K.R. and Bambawale, O.M., 2011. Spatio-temporal distribution of host plants of cotton mealybug, Phenacoccus solenopsis Tinsley in India. Technical Bulletin No. 26, NCIPM, Pusa Campus, New Delhi, pp. 1-50.

Yu, J.Z., Chi, H. and Chen, B.H., 2013. Comparison of the life tables and predation rates of Harmonia dimidiata (F.) (Coleoptera: Coccinellidae) fed on Aphis gossypii Glover (Hemiptera: Aphididae) at different temperatures. Biol. Contr., 64: 1-9. https:// doi.org/10.1016/j.biocontrol.2012.10.002

Yu, J.Z., Chi, H. and Chen, B.H., 2005. Life table and predation of Lemnia biplagiata (Coleoptera: Coccinelidae) fed on Aphis gossypii (Homoptera: Aphididae) with a proof on relationship among gross reproduction rate, net reproductive rate and preadult survivorship. Annls. entomol. Soc. Am., 98: 475-482. https://doi.org/10.1603/00138746(2005)098[0475:LTAPOL]2.0.CO;2 